\title{
Feeding the next billion: hunger and conservation
}

\author{
William M. AdAms
}

Sometime in October 2011 the human population reached seven billion. The date is uncertain-nobody knows exactly how many people there are as national censuses are intermittent and many inaccurate (Bloom, 2011). But the exact date does not matter: this was a political not demographic event. The seven billionth child was deemed by the UN to have been a girl, born in Manila, Philippines.

The point is not the identity or date of birth of the child, it is the number. Seven billion people are a lot, and predicted to grow-to eight billion by 2030 and nine billion by 2050 (UN, 2004).

How should conservationists think about a world of seven billion, or eight? Most will see population growth as part of what the UK's Chief Scientific Adviser, Sir John Beddington, called a 'perfect storm' of shortages of food, water and energy resources (Sample, 2009). Beddington predicted that population growth and poverty alleviation will trigger a surge in demand for resources by 2030, unleashing public unrest, cross-border conflicts and mass migration.

At the centre of Beddington's argument lies the problem of food supply. Not only has the human population risen but, under global competition, food conglomerates have slimmed supply chains and reduced food stores, particularly in developed economies. The price of commodities such as wheat and maize rose sharply in 2008, for example, as traders sensed a shortage, alarming policy makers.

The conventional response to high prices and hunger is to suggest growing more food. The Royal Society (2009) called for a new 'green revolution' driven by scientific innovation. This approach is not without problems. Conservationists know that modern intensive agriculture usually has catastrophic impacts on the environment. More critically, more food does not always lead to less hunger. Although we grow almost a fifth more calories per person today than in the 1980 s, hunger has increased: in 2010 the FAO estimated that 0.9 billion people were malnourished. Famine is generally the result of political economy rather than an absolute shortage of food (Sen, 1981; Nally, 2011).

Conservation's contribution to the debate about population and food has been cautious and mostly focused on two issues. One is the role of biodiversity in underpinning ecological processes and hence the ecosystem services of food production (Mace et al., 2012). The second is the impact of new agricultural technologies and intensified food

William M. Adams Department of Geography, University of Cambridge, Cambridge, UK. E-mail wa12@cam.ac.uk production on biodiversity. There has been extensive academic discussion of the relative merits of two approaches to minimizing the biodiversity loss associated with agriculture (Green et al., 2005; Fischer et al., 2008). The first is land sparing (minimizing the area of land needed for agriculture by increasing yields on smaller areas). The second is land sharing (the development of wildlife-friendly farming over larger areas of farmland). Research on bird and tree diversity in agricultural landscapes in Ghana and India suggests that land sparing may allow more species to survive (Phalan et al., 2011a).

However, as Fischer et al. (2011) argue, the way the landsparing versus land-sharing debate is framed as a stark choice is problematic: such a choice is rarely available in landscapes already owned and managed by different interest groups. They criticize simplistic thinking about land sparing that ignores rural livelihoods, the dependence of poor people on local ecosystem services, poor governance, and the impacts of agricultural intensification such as expanded use of agrochemicals.

The land-sparing argument makes some heroic assumptions. Firstly, it assumes that intensive agriculture has no side effects on biodiversity. Secondly, for a land-sparing strategy actually to reduce land conversion it would be necessary to have success in persuading landowners not to convert their land, to prevent others coming in and doing so illegally, and to prevent people unable to make a living as a result of the policy from going somewhere else to convert land: not easy to achieve. Thirdly, for such a strategy to be socially neutral it would be necessary to ensure that poor farmers are not displaced (e.g. by richer farmers or farm businesses buying or taking their land), or otherwise disadvantaged. Fourthly, for a land-sparing strategy to be compatible with the reduction of hunger it would be necessary to demonstrate how the greater food produced by intensive agriculture would actually reach the poor.

Land sparing is likely to be a good strategy for conservation under some conditions but not all (Fischer et al., 2008; Phalan et al., 2011b). It may be relevant on the agricultural frontier, where land-use planning is strong and effective, or where land is controlled by a single organization (e.g. the state or a large private owner), or by a small number of large owners who can be persuaded or incentivized to leave some land unconverted. However, where land is owned by multiple owners (particularly smallholders who lack capital) or is already a mosaic of ecosystem fragments and farmland, land sparing would be impossibly complicated to implement, especially in countries where governance is weak: peasant resistance can be remarkably effective 
(Scott, 1985). It would also be likely to lead to all kinds of social impacts as it inherently favours larger and richer landowners and corporate food system businesses that have the capital to innovate.

But what are the prospects for biodiversity where land sparing is not appropriate? Under what conditions does low-yield farming benefit biodiversity (Wright et al., 2012)? Can wild species in shared, farmed landscapes persist in the face of changing technology, demand, and farmers' needs? How can small-scale farmers can be persuaded or incentivized to maintain biodiversity on their land?

These are important questions that need to be addressed because pressure to convert land for agriculture is likely to grow inexorably (McLaughlin, 2011). It will be driven not by the slender pockets of the poor but the boundless appetites of the rich, and those escaping poverty, for meat, soya, palm oil and other feedstocks of the global food industry. In the coming agricultural revolution, the poor will be bystanders.

The Royal Society (2009) called for increased global food production 'without damage to societies and the environment'. But how is this to be achieved? Their solution is 'large scale sustainable intensification'. But how can the scattered examples of sustainable agriculture (Pretty et al., 2011) be mainstreamed? Where will biodiversity be in these new agricultural landscapes?

Creation of a global food system that 'satisfies human needs, reduces its carbon footprint, adapts to climate change and is in balance with planetary resources' (CSACC, 2011) is a huge challenge, requiring actions implemented at scale and urgently (Beddington et al., 2011). It demands a strong engagement by conservationists, working with farmers, agricultural scientists and agribusiness (Steiner, 2011), to help develop farming systems that create opportunities for nature at all levels from furrow to field and landscape. Several tasks are of great urgency. We need to understand how to maximize biodiversity and sustain ecosystem function under highly productive agriculture of many kinds. We also need to decide how to create institutions and incentives to persuade individual landowners to maximize biodiversity alongside yield and profit per hectare. Last, but not least, we need to help create the governance systems, markets, and capacity to support pro-biodiversity decisions on land use.

Protected areas, land spared from agriculture or marginal to it, are central to the future of conservation (McLaughlin, 2011). But so too is the survival of biodiversity in landscapes supplying human material needs (Wright et al., 2012). Otherwise, what is the chance the earth's eight billionth child will grow up to experience nature and their place in it? What is the chance they will grow up a conservationist?

\section{Acknowledgements}

Thanks to Andrew Balmford, Martin Fisher, Rhys Green and Chris Sandbrook for comments: remaining errors and arguments are my own.

\section{References}

Beddington, J., Asaduzzaman, M., Fernández, A., Clark, M., Guillou, M., Jahn, M. et al. (2011) Achieving Food Security in the Face of Climate Change: Summary for Policy Makers from the Commission on Sustainable Agriculture and Climate Change. CGIAR Research Program on Climate Change, Agriculture and Food Security, Copenhagen, Denmark

B Lоом, D.E. (2011) 7 billion and counting. Science, 333, 562-569. CSACC (2011) The Commission on Sustainable Agriculture and Climate Change. Http://ccafs.cgiar.org/commission/ [accessed 5 January 2012].

Fischer, J., Brosi, B., Daily, G.C., Ehrlich, P.R., Goldman, R., Goldstein, J. et al. (2008) Should agricultural policies encourage land sparing or wildlife-friendly farming? Frontiers in Ecology and the Environment, 6, 380-385.

Fischer, J., Batáry, P., Bawa, K.S., Brussaard, L., Chappell, M.J., Clough, Y. et al. (2011) Conservation: limits of land sparing. Science, 334, 593-594.

Green, R.E., Cornell, S., Scharlemann, J.P.W. \& Balmford, A. (2005) Farming and the fate of wild nature. Science, 307, 550-555.

Mace, G.M., Norris, K. \& Fitter, A.H. (2012) Biodiversity and ecosystem services: a multilayered relationship. Trends in Ecology \& Evolution, 27, 19-26.

McLaughlin, D.W. (2011), Land, food, and biodiversity. Conservation Biology, 25, 1117-1120.

Nally, D. (2011) Human Encumbrances: Political Violence and the Great Irish Famine. University of Notre Dame Press, Notre Dame, USA.

Phalan, B., Onial, M., Balmford, A. \& Green, R.E. (2011a) Reconciling food production and biodiversity conservation: land sharing and land sparing compared. Science, 333, 1289-1291.

Phalan, B., Balmford, A., Green, R.E. \& Scharlemann, J.P.W. (2011b) Minimising the harm to biodiversity of producing more food globally. Food Policy, 36 (Supplement 1), S62-S71.

Pretty, J., Williams, S. \& Toulmin, C. (2011) (eds) Sustainable Intensification: Increasing Productivity in African Food and Agricultural Systems. Routledge, London, UK.

SAMPLE, I. (2009) World faces 'perfect storm' of problems by 2030, chief scientist to warn. Http://www.guardian.co.uk/science/2009/mar/18/ perfect-storm-john-beddington-energy-food-climate [accessed 6 November 2011].

Scotт, J. (1985) Weapons of the Weak: Everyday Forms of Peasant Resistance. Yale University Press, New Haven, USA.

SEn, A. (1981) Poverty and Famines: An Essay on Entitlement and Deprivation. Oxford University Press, Oxford, UK.

STEInER, A. (2011) Conservation and farming must learn to live together. New Scientist, 210(2808), 28-29.

The Royal Society (2009) Reaping the Benefits: Science and the Sustainable Intensification of Global Agriculture. The Royal Society, London, UK.

UN (2004) World Population to 230o. UN Division of Economic and Social Affairs, New York, USA.

Wright, H.L., Lake, I.R. \& Dolman, P.M. (2012) Agriculture: a key element for conservation in the developing world. Conservation Letters, 5, 11-19. 